\title{
Seminal vesicle involvement: a rare extranodal manifestation of non-Hodgkin's lymphoma
}

\author{
Nayha Handa, Deepak Rathinam, Anuradha Singh, Manisha Jana
}

Department of Radiodiagnosis, All India Institute of Medical Sciences (AlIMS), New Delhi, India

\section{Correspondence to} Dr Nayha Handa, nayhahanda@gmail.com

Accepted 16 December 2015

\section{DESCRIPTION}

A 21-year-old man diagnosed as having a case of stage IV diffuse large B-cell lymphoma with CD20 positivity on immunohistochemistry underwent a baseline contrast-enhanced CT (CECT) scan for staging. The CECT scan revealed extensive lymphomatous deposits in the orbit, paranasal sinuses, thyroid, pleura, lungs, liver, pancreas and bilateral kidneys, and in the cervical, mediastinal and retroperitoneal nodes. In addition, the left seminal vesicle was enlarged and hypodense (figure 1). The right seminal vesicle was normal. The urinary bladder and prostate were also normal. Further, an 18F-fluorodeoxyglucose positron emission tomography scan was performed, which also revealed uptake in the region of the left seminal vesicle with a standardised uptake value value of 19.3 (figure 2).

Tumours of the seminal vesicles can be primary or secondary. Primary tumours can be benign (adenomas, cystadenomas) or malignant (adenocarcinoma, cystosarco phyllodes, sarcomas, neuroendocrine tumours, lymphomas). Secondary tumours are those that spread from the prostate, rectum and bladder, or lymphomas. ${ }^{1}$

These lesions cannot be differentiated on imaging and the differential diagnosis is ultimately made by histological analysis. ${ }^{2}$

Lymphomas frequently involve extranodal structures in the abdomen, including the solid organs (liver, spleen, kidneys and pancreas) as well as the hollow viscus (the gastrointestinal tract). However, in the pelvis, the incidence rate of lymphomas in locations other than the lymph nodes, such as the urinary bladder, prostate, seminal vesicles ovary, uterus, cervix and vagina, is known to be very low.

Extranodal involvement is more common in non-Hodgkin's lymphoma and is seen in $20-40 \%$ of these cases. The gastrointestinal tract is involved in $10-30 \%$ of cases and the head and neck in $20 \%$. $^{3}$

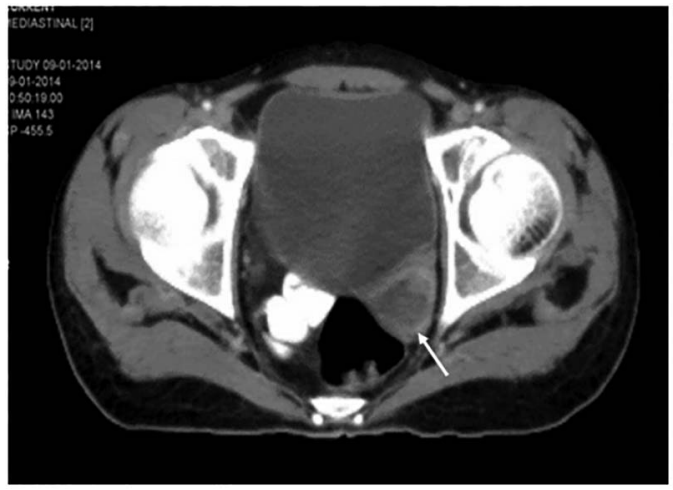

Figure 1 Axial contrast-enhanced CT (CECT) showing an enlarged and hypodense left seminal vesicle (arrow).

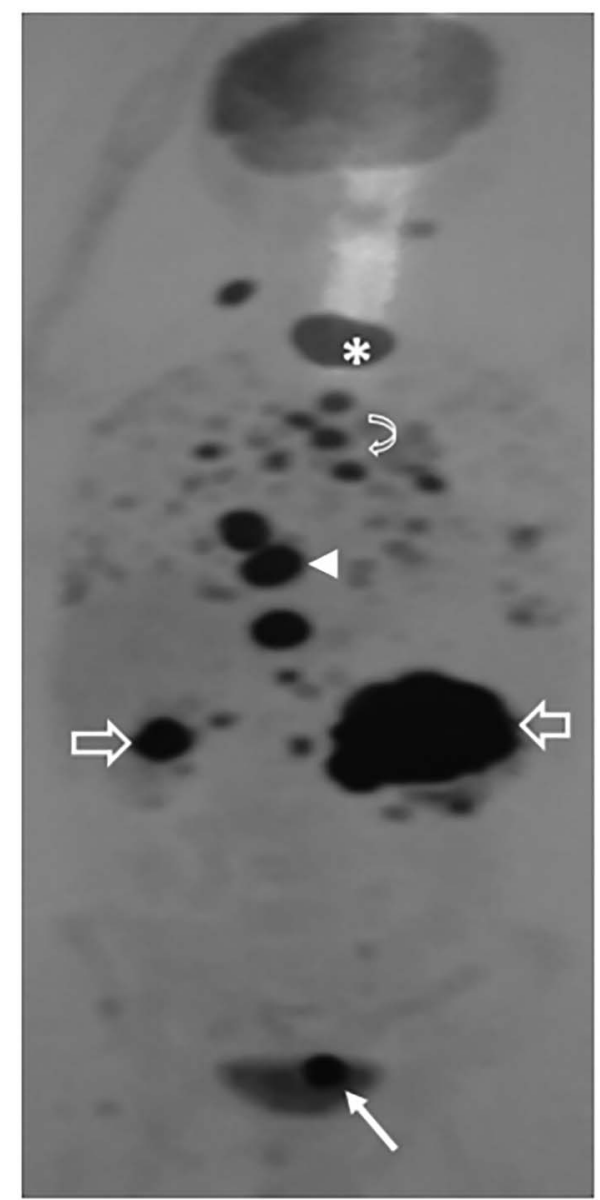

Figure 2 Maximum intensity projection images of positron emission tomography $\mathrm{CT}$ scan showing multifocal increased 18F-fluorodeoxyglucose (FDG) uptake in the thyroid (star), mediastinum (curved arrow), retroperitoneum (arrowhead), kidneys (outlined arrow) and left seminal vesicle (thin arrow)

\section{Learning points}

- Lymphomas can, rarely, involve pelvic organs such as the urinary bladder, prostate, seminal vesicles ovary, uterus, cervix and vagina.

- Malignancies occurring in the seminal vesicle are both primary and secondary, however, they have no characteristic imaging appearance.

Competing interests None declared.

Patient consent Obtained.

Provenance and peer review Not commissioned; externally peer reviewed. 


\section{REFERENCES}

1 Kreiner B, Denzinger S, Ganzer R, et al. Neuroendocrine carcinoma of the seminal vesicles presenting with Lambert Eaton syndrome: a case report. J Med Case Reports 2010;4:320.
2 Zhu J, Chen L, Zhang $X$, et al. Primary diffuse large B-cell lymphoma of the seminal vesicles: ultrasonography and computed tomography findings. Urology 2011;78:1073-4. 3 Charnsangavej C. Lymphoma of the genitourinary tract. Radiol Clin North Am 1990;28:865-77.

Copyright 2016 BMJ Publishing Group. All rights reserved. For permission to reuse any of this content visit http://group.bmj.com/group/rights-licensing/permissions.

BMJ Case Report Fellows may re-use this article for personal use and teaching without any further permission.

Become a Fellow of BMJ Case Reports today and you can:

- Submit as many cases as you like

- Enjoy fast sympathetic peer review and rapid publication of accepted articles

- Access all the published articles

- Re-use any of the published material for personal use and teaching without further permission

For information on Institutional Fellowships contact consortiasales@bmjgroup.com

Visit casereports.bmj.com for more articles like this and to become a Fellow 